
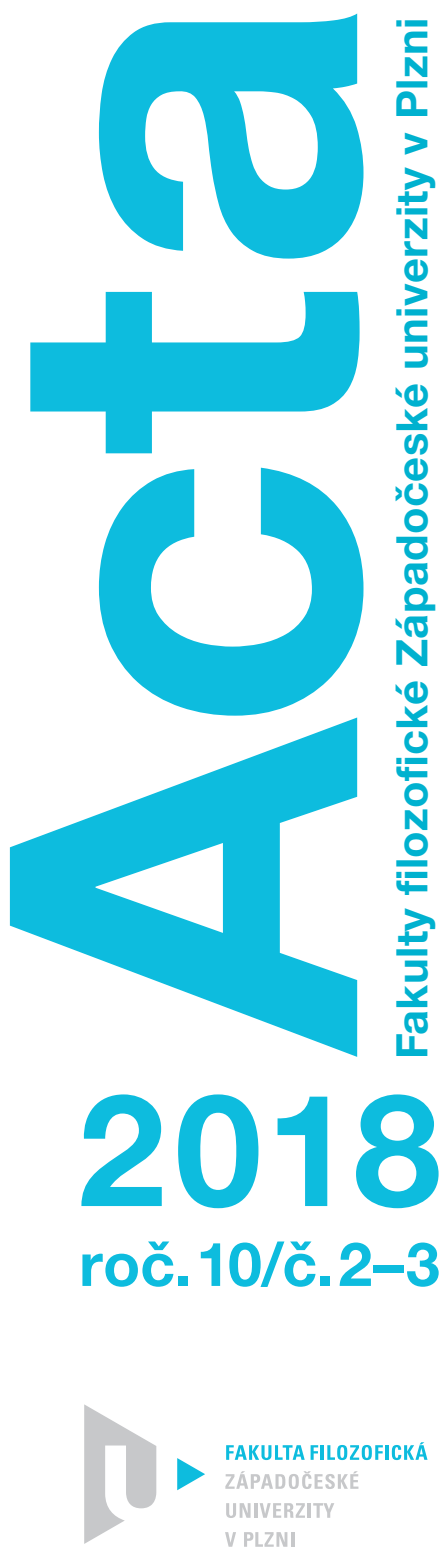


\title{
SLOVENSKÉ POLITICKÉ STRANY OPTIKOU KONCEPTU NOVOSTI*
}

\author{
Pavel Hynčica \& Daniel Šárovec**
}

\section{Slovak Political Parties through the Concept of Newness}

\begin{abstract}
The emergence and success of new political parties are one of the typical reflections of the dynamics of party system development. This phenomenon can also be observed in the context of gradual changes in the Slovak party system. Within it, the tension between established and new entities is evident and continuously transforms the overall character of political competition. The crisis of political elites and trust in political parties went along hand in hand with this process. This situation was an excellent starting point for new players. This qualitatively oriented comparative case study focuses on selected political entities of the Slovak party system that managed to succeed in the first-order elections, namely: Freedom and Solidarity (SaS), Ordinary People (OLaNO), the Slovak Conservative Party (SIET) and We Are Family. These parties are analysed in the context of theoretical approaches to studying new political parties. For this study, Alan Sikk's concept of novelty, based on Paul Lucardie's findings, was successfully used in other cases. This concept sets forth four ideal types of new political parties: prolocutors, purifiers, prophets and the project of newness. The results of the analysis have shown that, despite the possible difficulties of the chosen approach, the selected new entities could be contextually mapped and compared in the respective categories. All of the analysed subjects of significant success achieved it progressively, and each of the parties was in principle oriented differently. The role of leaders was an essential connecting feature. Some identical profile characteristics can be found among these new and successful entities.
\end{abstract}

Key words: newness, new political parties, Slovakia, Slovak party system, political parties.

DOI: https://doi.org/10.24132/actaff.2018.10.2-3.1

*Daniel Šárovec text zpracoval v rámci programu Progres Univerzity Karlovy Q18 Společenské vědy: od víceoborovosti $k$ mezioborovosti.

** PhDr. Pavel Hynčica, Ph.D., Katedra politologie a filozofie, Filozofická fakulta, Univerzita Jana Evangelisty Purkyně, pavel.hyncica@seznam.cz, Mgr. Daniel Šárovec, Katedra politologie, Institut politologických studií Fakulty sociálních věd, Univerzita Karlova, daniel.sarovec@fsv. cuni.cz. 


\section{1. ÚVOD}

Nástup nových politických stran je často nepřehlédnutelným jevem, který vyvolává potřebu systematického politologického zkoumání. Analýza tohoto fenoménu necílí na pouhé prosazení se nově vzniklého politického subjektu, at již ve smyslu doplnění stranického systému některým z dalších aktérů, nebo etablování nové stranické formace místo některé $\mathrm{z}$ těch stávajících. Stále jsou patrné fundamentální proměny v charakteru politiky, do jejíhož prostoru vstupují často obtížně definovatelné politické subjekty, které se od těch tradičních ${ }^{1}$ liší. Tyto odlišnosti mohou být ideově programového charakteru, zpo̊sobu komunikace s voliči nebo organizační strukturou a s tím souvisejícím způsobem fungování.

Cílem této interpretativní případové studie je analýza politických subjektů, které se v posledních letech etablovaly na slovenské politické scéně, a to s využitím politologických konceptů nových politických stran. V první - teoretické části budou představeny teoretické základy a koncepty nových politických stran a v návaznosti na to bude v interpretativní části textu analyzován charakter vybraných politických formací. Na Slovensku lze velmi výrazně pozorovat jevy v podobě nástupu a prosazení se nových politických subjektů, a to do takové míry, že jednou z významných dimenzí mezistranické soutěže se stává konfliktní linie mezi etablovanými politickými subjekty a právě těmito novými uskupeními. Ty se vůči starým stranám vymezují úsilím o prosazování tzv. nové politiky.

Důraz je kladen na nástup, charakteristické rysy a roli nových politických subjektů, které se na slovenské politické scéně prosadily v posledních letech. Pozornost bude upřena zejména na poslední tři volební období 2010-2012, 2012-2016 a období po posledních parlamentních volbách v březnu roku 2016. Konkrétně jde o strany Svoboda a Solidarita (SaS), Obyčejní lidé a nezávislé osobnosti (OLaNO), SIEŤ a SME RODINA. Tyto subjekty se v mnohém odlišují právě od těch formací, které dosud konstituovaly slovenský stranický systém. Ve všech zmíněných případech se jedná o politické subjekty, které přispěly v poslední době k fundamentálním proměnám ve vzorcích volební a mezistranické soutěže. Jde o politické formace vymezující se právě vůči tradičním stranám. S tím jde ruku v ruce to, že se jedná o strany akcentující význam politické změny. ${ }^{2}$

Dále jsou to strany s velmi osobitou organizační strukturou a s tím souvisejícím způsobem financování. Nepřehlédnutelná je zde role ústředního lídra a v neposlední řadě mnohé inovativní přístupy, které se týkají politické propagace, volebních kampaní, politického stylu nebo komunikace. V tomto směru se jedná o celou řadu jevů, na něž je více než vhodné se optikou zvolených přístupů zaměřit.

\footnotetext{
${ }^{1}$ Používejme i jako synonyma označení etablované či standardní politické subjekty - viz dále.

${ }^{2}$ Místy jde až o zásadní změnu vůči zažitým způsobům realizace politiky ze strany stávajících politických reprezentací, o opozici vůči stávajícímu politickému systému či o anti-establishment politiku.
} 


\section{VÝZKUM NOVÝCH POLITICKÝCH STRAN: TEORETICKÉ PŘÍSTUPY A METODOLO- GICKÉ OTÁZKY}

Problematika výzkumu nových politických stran je jednou z integrálních součástí šíreji orientovaného výzkumu politických stran. Toto téma se stabilně prosazuje zhruba od 70.-80. let 20. století (Šárovec 2016: 15), přičemž jeho důležitost je patrná i v současném světovém, slovenském i českém výzkumu (za všechny lze v rámci výběru jmenovat např. Lucardie 2000; Barnea, Rahat 2010; Hanley 2011; Hino 2012; Sikk 2012; Arter 2016; Maškarinec, Bláha 2014; Conti, Memoli 2015; Deegan-Krause, Haughton 2015; Žúborová 2015; Bolleyer, Bitzek 2016; Engler 2016; Charvát, Just 2016; Havlík, Voda 2016; Stauber 2017 nebo Šárovec 2018). ${ }^{3}$

Příslušné studie se snaží hledat odpovědi na otázky, co je to nová politická strana, jak konceptualizovat zkoumání nových politických stran, kterak stanovovat příslušné analytické rámce, jakož i mezi kterými proměnnými a jejich korelacemi lze hledat příčiny vzniku a vzestupu nových politických stran. Z hlediska pojmového ukotvení je třeba primárně vymezit kategorii nové politické strany. Tento pojem se často pokládá do opozice vưči starým, tradičním či etablovaným stranám (srov. Barnea, Rahat 2010), což jsou označení souhrnně reprezentující již existující politické subjekty působící v rámci konkrétní stranické soutěže. ${ }^{4}$

Text se přidržuje širšího pojetí kategorie nových politických stran, tj. pozornost bude zacílena na subjekty, které od svého vzniku poprvé uspěly v parlamentních volbách. To přirozeně zahrnuje i strany, které působí na slovenské politické scéně již delší dobu. ${ }^{5,6}$ Primárním cílem předkládaného textu je zaměření na typologizaci jednotlivých empirických případů. Jako hlavní teoretický rámec byl zvolen přístup Allana Sikka (2012), ${ }^{7}$ který navazuje na koncepci Paula Lucardieho (2000). ${ }^{8}$ Výsledkem jsou čtyři ideální typy nových politických stran, které představuje Tabulka 1.

Tabulka 1: Sikkova rozšírená typologie nových politických stran

Zaujímá strana místo již získané etablovanou stranou?

\begin{tabular}{lccc} 
& & + & - \\
\hline Ideologická motivace & silná & očištovatelé & proroci \\
slabá & projekt „novosti“ & mluvčí \\
\hline
\end{tabular}

Zdroj: Sikk (2012: 467)

\footnotetext{
${ }^{3}$ Pro širší vhled do problematiky jednotlivých proudů výzkumu nových politických stran v kontextu ČR viz Šárovec (2016, případně 2017).

${ }^{4}$ Lze vysledovat přirozené odlišnosti a nuance mezi pojmy stará, tradiční, zavedená nebo etablovaná politická strana, text si však neklade za cíl se touto problematikou zabývat detailněji. Pro účely zjednodušení je pojmově vnímá jako synonyma jsoucí v opozici k termínu nová politická strana.

${ }^{5}$ Tím se rozumí časový horizont několika posledních let.

${ }^{6}$ Především v případě jednoho zkoumaného subjektu - Svoboda a Solidarita (SaS) - máme co do činění s případem formace, která figurovala již ve třech po sobě jdoucích parlamentních volbách $(2010,2012,2016)$, a naskýtá se tedy otázka, zda a za jakých okolností ji vůbec můžeme považovat za novou.

${ }^{7}$ Allan Sikk se problematice nových stran věnuje i ve své studii z roku 2005 (viz Sikk 2005).

${ }^{8}$ Viz Hanley 2011; Žúborová 2015 nebo Šárovec 2018.
} 
Strany mluvčích (prolocutors) artikulují konkrétní zájem, ale nereprezentují přímou ideologii; strany očištovatelů či vyzyvatelů (purifying parties, purifiers nebo challengers) jsou subjekty lpící na ideologii, která je oslabena či zrazena jednou nebo více etablovanými stranami, strany proroku (prophets nebo prophetic parties) v závislosti na nových či aktuálních tématech ${ }^{9}$ rozvíjí nové ideologie či nová témata, a konečně strany projekt novosti (project of newness) usilují o vstup do té části politického spektra, které je již reprezentováno jinými politickými stranami ${ }^{10}$ (Lucardie 2000; Sikk 2012).

Vhodnost a aplikovatelnost tohoto přístupu již byla v kontextu slovenských nebo českých politických stran několikrát prokázána (viz Hanley 2011; Žúborová 2015 nebo Šárovec 2018). Obdobný, a nutno říci, že zdařilý výzkum realizovala zmiňovaná Viera Žúborová (2015), která se soustředila na komparaci českých a slovenských reálií. Nicméně daný text zachycuje analýzu vývoje pouze do roku 2015, a navíc se na danou problematiku zaměřuje optikou odlišného přístupu. Předložený text proto chce být komplementárním prvkem a dalším vkladem do současného a aktuálního stavu poznání zaměřeného na aktualizovanou analýzu nových politických stran na Slovensku.

Důvodem pro samotné širší pojímání fenoménu nových politických stran je zmiňovaný slovenský kontext $\mathrm{v}$ podobě zvýšené volatility stranického systému. ${ }^{11}$ Znovu je třeba podtrhnout význam dimenze sporu mezi starými a novými stranami na slovenské politické scéně v posledních letech. Již delší dobu působící politické subjekty jako SaS nebo OLaNO dokázaly sehrát (např́klad ve volbách 2016) roli nové alternativy vůči stávajícímu establishmentu, aspoň soudě dle jejich volebních úspěchů v atmosféře charakteristické zvýšené poptávce po změně (Michelko 2016: 6). Jistá konfliktní linie staré ${ }^{12}$ (SMER-SD, SNS, MOST-HÍD) versus nové (SaS, OLaNO, SME RODINA) politické strany projevila kooperačně-konkurenčními vztahy na politické scéně po volbách 2016 (viz též výše).

Zároveň je třeba věnovat prostor politickým subjektům, alespoň v dostatečné míře významným a relevantním (SaS, OLaNO), nebot pokud by byl záběr zúžen pouze na subjekty poprvé kandidující a prosadivší se (SIEŤ, SME RODINA), pak se $\mathrm{v}$ některých aspektech naskýtá otázka smysluplnosti věnované pozornosti s ohledem na příliš epizodní účinkování těchto subjektů na slovenské politické scéně - jejich rozpad a v jednom případě (SIEŤ) i faktická marginalizace, a to krátce po volbách.

Na základě popisu vzniku, vývoje, dosavadního účinkování, významných mezníků vnitrostranických i směrem navenek vymezených politických stran chce text

\footnotetext{
${ }^{9}$ Typicky např́íklad ekologická krize, anebo tenze mezi tradiční kulturou a přistěhovalci.

${ }^{10}$ Tyto strany lze nalézt především v zemích střední a východní Evropy. Jsou to subjekty, které slibují očištění politického života země - významné téma je například korupce - přesto ale zůstávají v ideologickém mainstreamu a nejsou antisystémové (Sikk 2012: 467; Š́avec 2018: 84-85). Důležité jsou v tomto směru také př́ípadné osobní ambice lídra, viz idiosynkratické strany (Lucardie 2000: 177).

${ }^{11}$ Dále je vzata v úvahu např́íklad i skutečnost, že role, význam, ideově programový profil či organizační struktura SaS plně odpovídá charakteristickým rysům mnoha nových politických stran etablovaných (na Slovensku i v některých dalších zemích) v nedávné nebo současné době. Jsou též reflektovány četné proměny SaS. Ta prošla jednak jedním výrazným procesem svého rozpadu a vedle toho se $\mathrm{v}$ některých aspektech též měnila její role v jednotlivých volbách.

${ }^{12}$ Respektive tradiční či etablované subjekty, viz výše.
} 
odpovědět na následující otázky: Byly motivace těchto subjektů převážně ideologické? Pokud ano, jaká byla a je jejich role na slovenské politické scéně ve vztahu $k$ dosud etablovaným politickým stranám? Pokud nikoliv, půjde primárně o subjekty artikulujici konkrétni zájmy bez ideologického zázemi? Samostatným problémem je do̊raz na projekt novosti - které strany primárně zdůrazňují tento aspekt a jak se to projevuje u konkrétního politického subjektu (ambice lídra, politický styl, konkrétní projevy vymezování se vůči stávajícímu establishmentu)? Jak se u zmíněných politických stran projevuje fenomén „,anti-politiky“, ,anti-establishmentu"?

\section{SLOVENSKÁ POLITICKÁ SCÉNA V ÉŘE NÁSTUPU NOVÝCH POLITICKÝCH STRAN}

Slovenský stranický systém je, například ve srovnání s tím českým, dlouhodobě považován za poměrně málo stabilní, značně proměnlivý a fragmentovaný (více např. Krno 1999; Henderson 2001; Hloušek, Kopeček 2004; Kopeček 2007). Charakteristická je celková slabá institucionalizace politických stran, naproti tomu však silná personifikace politiky, krátká životnost existujících a častý vznik nových subjektů částečně vyplňujících uvolněné místo po těch stávajících, v jiných případech však reagujících na nové situace. Tyto jevy zapadají do širšího kontextu komplikovanějšího politického vývoje na Slovensku od vzniku samostatného státu v roce 1993 (více např. Henderson 2001; Hloušek, Kopeček 2004; Leška 2010). Nástupem nových stran se slovenská politika stala $v$ ještě větší míře složitější. Tím spíše, že byla determinována a poznamenána mnoha komplikovanými, a v zásadě i často obtížně interpretovatelnými jevy.

Na Slovensku byla v posledních letech patrná postupující krize politických elit a politických stran a důvěry v ně a s tím související nárůst řady problémů. Sílila nespokojenost voličů se stávající politikou, což se naplno projevilo v parlamentních volbách 2016 (srov. Gyárfášová, Bahna, Slosiarik 2017 nebo Charvát, Just 2018). Frustrovaný volič v nich vyslal signál, že slovenská politika se musí změnit (Michelko 2016: 6). Nálady ve společnosti byly určovány významnými mezinárodně politickými faktory. Typickým tématem je například velmi silně rezonující uprchlická krize. Zásadní však byly domácí problémy, především tematika klientelismu, korupce a prohlubující se krize v některých oblastech, zejména justici, zdravotnictví, ale i školství. Ony zavedené politické strany projevovaly stále větší neschopnost reflektovat tyto závažné problémy a následně je řešit. Mnozí pozorovatelé slovenského politického dění považovali korupci za zásadní téma posledních parlamentních voleb (Michelko 2016: 6).

Slovenskou politickou scénu vymezovalo v uplynulém volebním období několik zásadních charakteristických rysů. Za první moment lze označit dominanci strany SMER-SD, která se v letech 2012-2016 projevovala existencí jednobarevné většinové vlády Roberta Fica. Široký záběr SMER-SD ve vztahu k voličům, a s tím související jeho vysoká voličská podpora, má své hlubší př́ičiny ideově programové, osobnostní i v podobě stavu politické konkurence (více např. Hynčica 2007; Blaha, Žanony 2008). Výrazná je v tomto ohledu dlouhodobá krize a roztř́ištěnost slovenské pravice, přičemž tato krize byla ještě podtrhnuta díky právě posilovanému konfliktu v dimenzi mezistranické soutěže ve smyslu staré versus nové politické 
strany. Dále je také třeba vnímat krizi a ve výsledku rozklad v minulosti jedné z nejvýznamnějších středopravicových formací SDKÚ-DS.

Druhá donedávna významná reprezentantka středopravicové politiky na Slovensku, tedy $\mathrm{KDH}$, se dlouhodobě vyznačovala nadměrnou politickou stabilitou na straně jedné, na straně druhé však postupujícím úpadkem zejména kvůli problému hermeticky uzavřené instituce a s tím související programové i personální stagnace (více např. Michelko 2012). ${ }^{13}$ Ten vyvrcholil volebním debaklem - KDH se poprvé od počátku své existence nedostalo do parlamentu.

V kontextu těchto činitelů není překvapující, že na slovenské politické scéně došlo v posledních několika volebních obdobích k etablování nových politických stran především na pravé straně politického spektra. Ty v zásadě plnily dvojí roli: (1) alternativy vůči sociálně demokratické straně SMER-SD a (2) alternativy vůči tzv. tradiční pravici reprezentované především SDKÚ-DS či KDH. Takto můžeme uvažovat především v případě SaS a OLaNO.

Souhrou řady faktorů zažily na Slovensku v posledních parlamentních volbách nebývalý debakl strany, které byly do nedávné doby nosnými pilíri slovenského stranického systému. Dosud vládnoucí SMER-SD zaznamenal volební vítězství, které je však mnohem méně výrazné než v minulých parlamentních volbách (viz dále Tabulky 2-4). V tomto př́ípadě se projevil přirozený obecný politický jev v podobě poklesu voličské přízně dlouhodobě vládnoucí politické strany, která nese odpovědnost za všechna, at již skutečná nebo domnělá, pozitiva i negativa svého vládnutí. Vedle toho se v konkrétní podobě projevovalo to, že vládní politici SMER-SD se museli vyrovnávat s četnými problémy a obviněními ze závažných skutků. ${ }^{14}$ SMER-SD jako politická strana symbolizující dosavadní politický establishment musel v těchto volbách více než kdy v minulosti čelit protestní volbě, která se projevila nebývalým úspěchem nových politických stran.

Zatímco však voličsky silný a stranicky zkonsolidovaný SMER-SD v posledních volbách v zásadě potvrdil své postavení významného subjektu na politické scéně, tzv. pravicové strany charakteristické dlouhodobou krizí své identity, personální výbavy i voličské přízně zaznamenaly právě v těchto volbách, poznamenaných přesuny voličské přízně směrem k novým politickým subjektům, totální porážku.

Zejména v kontextu dosud posledních parlamentních voleb 2016 poskytuje Slovensko mimořádně výraznou inspiraci ke studiu stran v kontextu konceptů novosti. Etablování nových politických stran vymykajících se zaužívaným a standardním typologiím představuje dnes již velmi rozšířený politický jev, který však na Slovensku dosáhl po volbách 2016 takové intenzity, která je i s vědomím této skutečnosti výjimečná. Odpovídají tomu i podoby kooperačně-konkurenčních interakcí mezi politickými subjekty, které jsou determinovány ve výrazné míře značnou mírou nekompatibility „starých“ a „nových“.

\footnotetext{
${ }^{13}$ To lze ze širší perspektivy vztáhnout například i na problematiku členských i expertních kapacit (v českém kontextu srov. např. s Perottino 2015).

${ }^{14}$ Vláda Roberta Fica byla ze strany opozice a velké části médií takřka permanentně obviňována z korupce a klientelismu. Sami politici SMER-SD museli v uplynulém volebním období pod tlakem některých skutečností reagovat. Týkalo se to zejména oblasti zdravotnictví (např́iklad kauza nákupu předraženého CT přístroje pro nemocnici v Pieštanech vedla k demisi ministryně zdravotnictví Zuzany Zvolenské, předseda NR SR Pavol Paška byl opakovaně obviňován zejména opozicí z klientelistických vazeb v oblasti zdravotnictví, nakonec odstoupil ze své funkce po krajských volbách v listopadu 2015).
} 
Mnozí politologové $\mathrm{v}$ tomto směru zdůrazňují význam linie sporu právě mezi těmito dvěma kategoriemi politických subjektů (Michelko 2016: 6). Tato skutečnost byla charakteristická v předvolební kampani, a navíc umocněná mimo jiné některými zvlášt silnými osobními antagonismy, a to především mezi předsedou SMER-SD Robertem Ficem a lídrem OLaNO Igorem Matovičem.

Výsledek v podobě zformování vládního spojenectví na bázi politických stran SMER-SD, Slovenská národní strana (SNS), MOST-HÍD a SIEŤ toto potvrdil. Vládní koalici utvořily subjekty, které byly dosud tradičními elementy slovenské politické scény reprezentujícími některý z jejích typických ideových směrů. At už šlo o sociálně demokratický segment v podobě SMER-SD, tzv. národovectví představované SNS, MOST-HÍD jako jedno z uskupení prosazující program postavený na obhajobě zájmů př́íslušníků madarské etnické menšiny na Slovensku.

Naproti tomu se v opozici zkoncentrovaly právě výrazné charakteristiky tzv. nového politického stranictví se všemi často velmi nevšedními jevy. Jmenujme např́iklad politický styl některých představitelů těchto uskupení, zejména lídra OLaNO Igora Matoviče, ${ }^{15}$ nebo velmi netypické fiktivní či hybridní organizace těchto uskupení, především OLaNO a SME RODINA.

Značná míra protikladu mezi starými a novými politickými stranami ve slovenské politice, a ještě větší zvýraznění tohoto jevu po volbách 2016 vynikne tím spíše, že zároveň s tím dochází $\mathrm{k}$ redefinici některých do této doby charakteristických vztahů. Pokud jde o protiklad tzv. slovenského národovectví a politiky postavené na obhajobě zájmů mad’arské etnické menšiny, jejíž reprezentanti, především SNS a MOST-HÍD, se po těchto volbách ocitli ve společné vládní koalici, můžeme hovořit o jednom z typických př́kladů. Jedná se o jev do této doby ve slovenských poměrech těžko představitelný.

Tabulka 2: Výsledky parlamentních voleb 2010 a rozdíl oproti volbám 2006

\begin{tabular}{lccccc}
\hline Politická strana & $\begin{array}{c}\text { Počet hlasů } \\
\text { (abs.) }\end{array}$ & $\begin{array}{c}\text { Počet hlasů } \\
(\mathrm{v} \%)\end{array}$ & $\begin{array}{c}\text { Počet } \\
\text { mandátů } \\
\text { (abs.) }\end{array}$ & $\begin{array}{c}\text { Rozdíl počtu } \\
\text { hlasů (v \%) }\end{array}$ & $\begin{array}{c}\text { Rozdíl počtu } \\
\text { mandátů } \\
\text { (abs.) }\end{array}$ \\
\hline SMER-SD & 880111 & 34,8 & 62 & $+5,7$ & +12 \\
SDKÚ-DS & 390042 & 15,4 & 28 & -3 & -3 \\
SaS & $\mathbf{3 0 7 2 8 7}$ & $\mathbf{1 2 , 1}$ & $\mathbf{2 2}$ & - & - \\
KDH & 215755 & 8,5 & 15 & $+0,4$ & -1 \\
MOST-HÍD & 205538 & 8,1 & 14 & $-6,6$ & -11 \\
SNS & 128490 & 5,1 & 9 & $-7,4$ & -20 \\
SMK & 109638 & 4,3 & - & $-4,5$ & -15 \\
LS-HZDS & 109480 & 4,3 & - & & \\
\hline
\end{tabular}

Zdroj: Štatistický úrad Slovenskej republiky (2010)

\footnotetext{
${ }^{15}$ Lídra OLaNO Igora Matoviče charakterizuje velmi radikální protestní rétorika a s tím související místy velmi extravagantní politický styl (více v další části).
} 
Tabulka 3: Výsledky parlamentních voleb 2012 a rozdíl oproti volbám 2010

\begin{tabular}{lccccc}
\hline Politická strana & $\begin{array}{c}\text { Počet hlasů } \\
\text { (abs.) }\end{array}$ & $\begin{array}{c}\text { Počet hlasů } \\
(\mathrm{v} \%)\end{array}$ & $\begin{array}{c}\text { Počet } \\
\text { mandátů } \\
\text { (abs.) }\end{array}$ & $\begin{array}{c}\text { Rozdíl počtu } \\
\text { hlasů (v \%) }\end{array}$ & $\begin{array}{c}\text { Rozdíl počtu } \\
\text { mandátů } \\
\text { (abs.) }\end{array}$ \\
\hline SMER-SD & 1134280 & 44,4 & 83 & $+9,6$ & +21 \\
KDH & 225361 & 8,8 & 16 & $+0,3$ & +1 \\
OLaNO & $\mathbf{2 1 8 5 3 7}$ & $\mathbf{8 , 6}$ & $\mathbf{1 6}$ & - & - \\
MOST-HÍD & 176088 & 6,9 & 13 & $-1,2$ & -1 \\
SDKÚ-DS & 155744 & 6,1 & 11 & $-9,3$ & -16 \\
SaS & $\mathbf{1 5 0 2 6 6}$ & $\mathbf{5 , 9}$ & $\mathbf{1 1}$ & $-\mathbf{6 , 2}$ & $-\mathbf{1 1}$ \\
SNS & 116420 & 4,6 & - & $-0,5$ & -9 \\
\hline
\end{tabular}

Zdroj: Štatistický úrad Slovenskej republiky (2012)

Tabulka 4: Výsledky parlamentních voleb 2016 a rozdíl oproti volbám 2012

\begin{tabular}{lccccc}
\hline Politická strana & $\begin{array}{c}\text { Počet hlasů } \\
\text { (abs.) }\end{array}$ & $\begin{array}{c}\text { Počet hlasů } \\
\text { (v \%) }\end{array}$ & $\begin{array}{c}\text { Počet } \\
\text { mandátů } \\
\text { (abs.) }\end{array}$ & $\begin{array}{c}\text { Rozdíl počtu } \\
\text { hlasů (v \%) }\end{array}$ & $\begin{array}{c}\text { Rozdíl počtu } \\
\text { mandátů } \\
\text { (abs.) }\end{array}$ \\
\hline SMER-SD & 737481 & 28,3 & 49 & $-16,1$ & -34 \\
SaS & $\mathbf{3 1 5 5 5 8}$ & $\mathbf{1 2 , 1}$ & $\mathbf{2 1}$ & $+\mathbf{6 , 2}$ & $+\mathbf{1 0}$ \\
OLaNO & $\mathbf{2 8 7 6 1 1}$ & $\mathbf{1 1}$ & $\mathbf{1 9}$ & $+\mathbf{2 , 4}$ & $+\mathbf{3}$ \\
SNS & 225386 & 8,6 & 15 & $+8,6$ & +15 \\
LSNS & 209779 & 8 & 14 & - & - \\
SME RODINA & $\mathbf{1 7 2} \mathbf{8 6 0}$ & $\mathbf{6 , 6}$ & $\mathbf{1 1}$ & - & - \\
MOST-HÍD & 169593 & 6,5 & 11 & $-0,4$ & -2 \\
SIET & $\mathbf{1 4 6 2 0 5}$ & $\mathbf{5 , 6}$ & $\mathbf{1 0}$ & - & - \\
KDH & 128908 & 4,9 & - & $-3,9$ & -16 \\
\hline
\end{tabular}

Zdroj: Štatistický úrad Slovenskej republiky (2016)

\section{SVoboda a Solidarita (SaS)}

Svoboda a Solidarita vznikla v roce 2009 (viz Tabulku 5). Pro tuto politickou formaci je klíčových několik charakteristik. Jde o zřetelnou liberálně pravicovou ideovou orientaci projevující se primárně v ekonomické oblasti. Kromě toho se jedná o další pokus vytvořit v podmínkách dlouhodobé krize slovenské pravice politický subjekt, který bude věrohodněji, efektivněji a důsledněji prosazovat takto orientovanou politiku ve srovnání se stávajícími liberálně konzervativními politickými stranami. A konečně třetí zásadní skutečností je naprosto nezastupitelná role předsedy SaS Richarda Sulíka. Všechny tyto tři faktory spolu přitom vzájemně souvisejí. Ideově programovou orientaci a tomu odpovídající politický styl SaS vtiskl Richard Sulík, liberální ekonom, který se jako specialista na daňovou problematiku mj. silně zasazoval za jeden z pilî́ro liberálně pravicové politiky - tzv. rovnou daň.

Programový profil SaS je charakteristický zřetelně liberální orientací v ekonomické oblasti, což zároveň koresponduje s nekompromisní kritikou sociálně ekonomické politiky SMERu (Sas.sk 2016; Mesežnikov 2013: 62). Svého prvního politického úspěchu dosáhla tato strana v parlamentních volbách v roce 2010 (viz Ta- 
bulku 2). Již tehdy se u této strany zřetelněji projevilo několik prvků novosti. SaS oslovovala voliče mnoha nestandardními prostředky. Především využívala v nadměrné míře moderních forem komunikace prostřednictvím internetových sociálních sítí (zjm. Facebook), čímž cílila zejména na mladou generaci. Před volbami také SaS rozeslala tisíce SMS zpráv a e-mailů.

Další skutečností bylo budování strany tzv. volebního typu. SaS se od počátku vyznačovala téměř absencí rozvinuté organizační struktury, například počet členů se pohyboval v řádu 200-300 (Mesežnikov 2013: 63), o to více však kladla důraz na oslovování voličů, a to pomocí efektivního politického marketingu a za účasti lídra s místy nevšedním politickým stylem. Richarda Sulíka dlouhodobě charakterizuje velmi suverénní způsob vystupování jdoucí proti principům tzv. politické korektnosti.

Před parlamentními volbami 2010 bylo pro politiku SaS zřetelné prolínání dvou rovin - již zmiňované ideově programové vymezování vůči SMER-SD ${ }^{16}$ a vedle toho prezentace jako strany nové, která kritizuje stávající politické strany jako subjekty př́liš spjaté s klientelismem a korupcí. Tato druhá rovina politiky SaS však byla cílena především právě vůči SMER-SD. V případě politických stran SMER-SD a SaS jsou patrné dva ostré protiklady umocňovanými kumulací vícero faktorů navzájem spolu souvisejících - ideově programové rozdíly a zároveň demonstrace opoziční politiky. Připomeňme si, že se SaS zformovala ve volebním období 20062010, tj. v době první vlády Roberta Fica (Mesežnikov 2013: 63).

Po parlamentních volbách 2010 následovalo dvouleté účinkování (2010-2012) ve středopravicové vládě Ivety Radičové. Dále se SaS profilovala jako politický subjekt s řadou vyhraněných názorů, které se projevovaly i v některých kontroverzních oblastech. Jedním z rozměrů programového profilu SaS, který stále více vystupoval do popředí, byl euroskepticismus. Ve volebním období 2010-2012 proslula SaS kritikou poskytnutí finanční pomoci Řecku. To byl pouze jeden z př́́kladů kritických názorů směrem k fungování EU. ${ }^{17} \mathrm{~V}$ souvislosti s prohlubující se ekonomickou krizí v některých státech EU připouštěla například SaS možnost vystoupení Slovenska z eurozóny a návrat národní měny. Zásadní a nejvýznamnější, i z hlediska dopadů na domácí politickou scénu, byl však kritický postoj SaS k Evropskému stabilizačnímu mechanismu (ESFS). Ten měl sloužit k podpoře států EU potýkajících se s hospodářskými a finančními problémy. SaS byla v tomto směru osamocena v rámci tehdejší pravostředové vládní koalice a důsledkem rozdílných názorů mezi SaS a ostatními koaličními stranami byl pád vlády Ivety Radičové.

Přestože uplynulo již několik let od etablování SaS na slovenské politické scéně, četné a již výše zmiňované prvky novosti přežívají na této straně dodnes a v tomto směru můžeme též chápat její prosazení se v parlamentních volbách 2016. Stejně jako ve volbách 2010, i ve volbách 2016 představovala SaS ideově vyhraněnou politickou stranu symbolizující výrazně odlišnou politiku než SMER-SD. S ohledem na politickou konstelaci ve volebním období 2012-2016 (jednobarevná vláda SMERu vs. SaS jako jedna z opozičních stran) mohla SaS hrát roli protestního

\footnotetext{
${ }^{16}$ Především šlo o důraz na prosazování výrazně jiné politiky než sociálně demokratické prosazované stranou Roberta Fica.

${ }^{17}$ Pro širší kontext celé problematiky ve středoevropském prostoru viz např. Hynčica, Maškarinec, Novotný (2017).
} 
subjektu poukazujícího na přehmaty establishmentu, respektive primárně vlády reprezentované SMER-SD. A konečně se zvýraznila role SaS jako politického subjektu symbolizujícího alternativu vůči politickému mainstreamu.

$\mathrm{V}$ tomto směru se posílil hlavně euroskeptický profil SaS, a to především díky uprchlické krizi. SaS patří k politickým stranám kritizujícím příliš liberální př́stup části evropských politických elit k přijímání uprchlíků. Opět tak vyniká nepřehlédnutelný politický styl stranického lídra Richarda Sulíka, který se například i prostřednictvím německých médií nebo na půdě Evropského parlamentu vymezoval vůči německé kancléřce Angele Merkelové, hlavní protagonistce politiky vstřícnosti vůči uprchlíkům (Európske noviny 2015; Deutschlandfunk.de 2016).

Zvýraznění ,antificovské“, anti-establishment či euroskeptické rétoriky v politice SaS v průběhu posledních let bylo dáno též přeskupením sil v rámci strany. V uplynulém volebním období se od SaS oddělila část jejích politiků ${ }^{18}$ která založila vlastní politickou stranu SKOK. Po této stranické secesi se ještě více upevnilo již tak dominantní postavení lídra Richarda Sulíka ve straně, který právě nejvíce symbolizoval politiku do̊sledného odmítání programové spolupráce se stranou SMER-SD a s tím související přetrvávající anti-politiku postavenou na místy nevšedním politickém stylu. Toto bylo posíleno právě postavením SMER-SD jako vládní strany, vůči které byla SaS v opozici. Připomeňme též zmiňovaný euroskepticismus, primárně ekonomický, ale též upevněný uprchlickou krizí.

Politika odštěpenců ze SKOK byla v tomto směru mnohem méně výrazná. SKOK neměla ve svém čele výraznou politickou osobnost, kterou by mohli voliči chápat jako nositele alternativy, profilovala se jako liberální strana víceméně v mantinelech proevropského politického mainstreamu, přičemž kritizovala především euroskeptickou agendu SaS. Podle SKOK byl program SaS i vystupování jejího předsedy Richarda Sulíka v rozporu s liberálními principy (Noviny.sk 2017).

V parlamentních volbách 2016 se v případě role a výsledků SaS projevila značná míra koncentrace a korelace ideologicky vyhraněné (vůči sociální demokracii), protestně zaměřené ${ }^{19}$ a pravidlo̊m politické korektnosti ${ }^{20}$ se vymykající politiky, což posílilo povědomí o této straně jako zřetelné alternativy s prvky novosti.

Tabulka 5: Hlavní mezníky ve vývoji subjektu SaS

\begin{tabular}{ll}
\hline Politický subjekt: & Svoboda a Solidarita (SaS) \\
Rok vzniku: & 2009 \\
První volby do NR SR: & 2010 \\
Zastoupení v NR SR: & $2010-2012,2012-2016,2016-$ \\
Účast ve vládě: & $2010-2012$
\end{tabular}

Zdroj: autoři dle Štatistický úrad Slovenskej republiky

\footnotetext{
${ }^{18}$ Například Jozef Kollár, Juraj Miškov nebo Daniel Krajcer.

${ }^{19}$ Především vůči establishmentu, a s tím související protikorupční apel.

${ }^{20}$ Typicky se zde objevuje akcent na společensky citlivá témata, např. přístup k uprchlické krizi.
} 


\section{Obyčejní lidé a nezÁvislé Osobnosti (Ol'ANO)}

Toto politické uskupení se poprvé projevilo v parlamentních volbách 2010 (viz pozn. pod čarou), ve kterých pod hlavičkou Obyčejní lidé (OL) kandidovala skupinka čtyř lidí vedená Igorem Matovičem. Ten vešel ve známost díky své činnosti jednatele sítě bezplatných regionálních novin RegionPRESS. Matovič již ve volebním období 2006-2010 vydával své noviny, ve kterých především ostře kritizoval politiku v té době vládnoucího uskupení politických stran SMER-SD, SNS a L'S-HZDS. Zaměřoval se především na dlouhodobě palčivý problém klientelismu a korupce. Skupina Obyčejných lidí se ve volbách 2010 dostala do NR SR na kandidátce SaS, a to z jejích posledních míst pomocí preferenčních hlasů.

Ve volebním období 2010-2012 se skupina Obyčejní lidé postupně emancipovala od SaS. V listopadu 2011 byla registrována jako samostatné politické uskupení, které šlo samostatně do parlamentních voleb 2012. Šlo o politickou formaci $\mathrm{s}$ výrazně nestandardními prvky vymykajícími se principům politického stranictví. Obyčejní lidé nebyli nikdy klasickou politickou stranou, ale skupinou bez organizační struktury nebo členské základny. Například ještě na konci roku 2012, tedy 9 měsíců poté, co se ve volbách dostal tento subjekt samostatně do parlamentu, měl pouze 4 členy ${ }^{21}$ (Mesežnikov 2013: 69). S tím pak souvisí výrazná dominance lídra Igora Matoviče, který své uskupení nejen založil, ale i zafinancoval, přičemž se v tomto směru výrazně prolíná jeho činnost politická a podnikatelská.

Role Igora Matoviče jako jednatele firmy RegionPRESS je nepřehlédnutelná z hlediska fungování OLaNO. Matovič svou firmu nechal v roce 2007 přepsat na svou manželku Pavlínu, což ale nic nemění na tom, že je v politických či mediálních kruzích opakovaně poukazováno na nadměrné prolínání politické strany OLaNO a firmy zejména s ohledem na způsoby financování. Jde o možné využívání státních př́spěvků, které dostává OLaNO jako politická strana v Matovičových rodinných firmách (Pravda.sk 2016). Dominance lídra ve spojení s nerozvinutou organizační strukturou vynikne ještě více, když vezmeme v úvahu, že někteří ze čtyř nejbližších spolupracovníků Igora Matoviče v OLaNO jsou s ním v př́buzenském vztahu, např́klad bratranec Jozef Viskupič.

Igor Matovič představuje osobitý fenomén slovenské politiky. Původně živnostník vstoupil do politiky primárně z důvodu nespokojenosti s jejím stavem. Od počátku se přitom prezentoval velmi nevšedním politickým stylem, který byl charakteristický několika prvky: radikální anti-establishment rétorikou, nestandardními formami komunikace prostřednictvím happeningů s akcenty na zjednodušenou symboliku a vnější pózu, ${ }^{22}$ a také různými formami komunikace vybočující z pravidel tzv. politické korektnosti, mezi které patří též četná obviňování politických konkurentů. ${ }^{23}$

\footnotetext{
${ }^{21}$ Šlo o stejnou skupinu čtyř lidí, kteř́ kandidovali ve volbách 2010 na kandidátce SaS a kteří tvořili a dosud tvoří jádro Obyčejných lidí (Igor Matovič, Jozef Viskupič, Erika Jurinová, Martin Fecko).

${ }^{22}$ Tím se myslí např́íklad transparenty, trička s nápisy, a to na půdě parlamentu i mimo něj.

${ }^{23}$ Například krátce po parlamentních volbách 2010 prohlásil, že mu bylo nabízeno 20 miliónů eur za to, že přispěje k pádu vlády Ivety Radičové. Ve druhé polovině roku 2015 obvinil premiéra Roberta Fica z toho, že si spolu s manželkou založil tajný účet na Belize, na kterém skrývá množství finančních prostředků v hodnotě několika stovek miliónů dolarů (Hlavnespravy.sk 2015).
} 
U Obyčejných lidí lze definovat dva výrazné charakteristické rysy, které spolu vzájemně souvisejí. Již zmiňovaná absence organizační stranické struktury jde ruku v ruce s politikou protestu. Uskupení se od počátku vymezovalo vůči dosavadnímu zpo̊sobu politiky tak, jak ji realizovaly dosud etablované politické strany. Obyčejní lidé jsou tak př́́kladem toho, co je hodnoceno jako antipozice k politickým stranám neboli „anti-strana“ (Mesežnikov 2013: 69).

Přesto se před parlamentními volbami Matovičovo uskupení rozšířilo, ale nikoliv ve smyslu přetvoření ve standardní politickou stranu, ale zformování sítě nezávislých osobností majících zájem se politicky angažovat. V souladu s touto ideou tak do parlamentních voleb 2012 šlo uskupení již pod hlavičkou Obyčejní lidé a nezávislé osobnosti (OLaNO). Uskupení v této podobě se skládalo z několika skupin lidí. Jádrem OLaNO jsou zmiňovaní nejbližší spolupracovníci Igora Matoviče, dalším segmentem byly osobnosti z oblasti veřejného života (Mikuláš Huba) a občanští aktivisté, z nichž někteří (zejména Alojz Hlina) zvýrazňovali antipolitický/anti-establishment charakter hnutí. Na druhé straně bylo pro OLaNO charakteristické zakotvení na pravé části politického spektra, což dokládalo spojení se dvěma menšími pravicovými stranami Občanskou konzervativní stranou (OKS) a Konzervativními demokraty Slovenska (KDS).

Z dlouhodobého hlediska marginální jev v podobě spojení Obyčejných lidí s OKS a KDS ukazuje na jedné straně na určité zakotvení tohoto subjektu v jedné, v tomto př́ípadě pravostředové části politického spektra, které je již reprezentováno jinými politickými stranami. Více však ukazuje na anti-establishmentový charakter hnutí. Před volbami 2012 totiž z avizovaného spojení Matovičova hnutí s OKS a KDS sešlo, a to za zajímavých okolností. Pod tlakem vypuknutí tzv. kauzy Gorila požádal Igor Matovič politiky těchto stran, aby podstoupili detektor lži, který měl prokázat či vyvrátit jejich spoluúčast na nekalých praktikách a korupčním chování v minulosti (Mesežnikov 2013: 69).

V tomto směru můžeme hovořit o protikladu politika Matoviče, demonstrujícího nový přístup v politice ve spojení s okázalým a nevšedním politickým stylem, a politických stran, jejímiž reprezentanty byli bývalí, v některých případech i dlouholetí politici. Např́iklad KDS vznikla odštěpením od dlouhodobě „v systému zakotveného" KDH.

Při analýze charakteristických znaků OLaNO je užitečné srovnání s SaS. Pokud jde o ideově programovou orientaci a míru ideologického vyhranění, to je v př́ípadě OLaNO méně zřetelné. Jak již bylo řečeno, uskupení je zasazené ve středopravicové části politického spektra, hojná je však jeho charakteristika jako formace nepolitické, amorfní, vyznačující se absencí jasného ideologického profilu, strany tzv. „zdravého rozumu“ (Mesežnikov 2013: 77).

Ve srovnání s SaS jsou v politice OLaNO zřetelně výraznější prvky anti-politiky a protestu. Již ve dvou po sobě následujících parlamentních volbách 2012 a 2016 dominovala v politice OLaNO agenda korupce a celkově kritika dosavadního způsobu uplatňování politiky zavedenými stranami, čemuž odpovídá i personální složení hnutí. V obou volbách se projevila převažující ideově programová orientace a tendence k zakotvení v rámci standardního ideologického rozvrstvení politického spektra. To lze ukázat např́klad na spojení s politickou stranou NOVA, která do jisté míry ve vztahu k OLaNO představuje podobný př́íklad jako ve volbách 
2012 OKS a KDS - uskupení s ideově programovým zakotvením a reprezentované politikem etablovaným v rámci dosavadních elit. ${ }^{24}$ Více se však ve volbách 2016 projevil právě anti-politický charakter hnutí mj. tím, že páteř její kandidátky tvořili občanští aktivisté spolupracující s nevládními organizacemi. ${ }^{25}$

Co se týče organizační struktury, ta je v případě SaS málo rozvinutá. OLaNO jako subjekt svou podobou zcela popírá principy stranictví, a proto lze říci, že jde spíše o neformální hnutí sympatizantů a blízkých Igora Matoviče. Jedná se o ukázkový př́iklad politické formace, která namísto jasné strukturace disponuje spíše volnou sítí sympatizantů s nejasnou mírou stability a loajality. Příkladem tohoto může být poslanecký klub OLaNO v NR SR, který se ve volebním období 2012-2016 potýkal ve značné míře s problémem odchodů svých poslanců a podobný jev se projevuje už i v současnosti. Druhou skutečností s tím související je pak značná míra obměny poslaneckého klubu OLaNO po volbách 2016 ve srovnání s předchozím volebním obdobím. ${ }^{26}$

Osobnostní založení předsedů obou formací je velmi nevšední, přičemž jejich převažující rysy se promítají do charakteru celých stran. ${ }^{27} \mathrm{~V}$ souladu s tím můžeme považovat OLaNO za příklad politického uskupení prosazujícího a akcentujícího témata mimo rámec běžných debat mezi politickými stranami, přičemž příznačné jsou nejen aspekty obsahové, ${ }^{28}$ ale i formální v tom smyslu, že politický styl OLaNO se dlouhodobě vymyká standardním mechanismům fungování politiky. ${ }^{29}$

Také OLaNO charakterizuje, stejně jako SaS, silný ideově programový i zájmový protiklad ke SMER-SD, přičemž v souladu s jeho celkovým založením vystupují v tomto ohledu do popředí především konkrétní témata a problémy, ${ }^{30}$ spíše vedlejší je pak kritika SMER-SD ve smyslu ideologickém. ${ }^{31}$ U SaS je ideologická motivace mnohem výraznější. ${ }^{32}$

Výrazně excentrický způsob vystupování lídra OLaNO Igora Matoviče posiluje již zmiňovaný silný osobní antagonismus předsedů ideově a zájmově protikladných formací SMER-SD a OLaNO. Uplynulé volební období (2012-2016) bylo ve

\footnotetext{
${ }^{24}$ Předsedou a zakladatelem NOVA byl bývalý dlouholetý reprezentant KDH Daniel Lipšic.

${ }^{25}$ Např́íklad blogerka Veronika Remišová nebo lékař Alan Suchánek.

${ }^{26} \mathrm{~V}$ minulém volebním období odešli ze šestnáctičlenného poslaneckého klubu OLaNO postupně Alojz Hlina, Štefan Kuffa, Mikuláš Huba nebo Mária Ritomská. Ze současného poslaneckého klubu prozatím odešli dva poslanci (Oto Žarnay, Viera Dubačová). Po volbách 2016 měl klub OLaNO 19 poslanců, z toho však pouze 5 z nich zůstalo z minulého volebního období.

${ }^{27}$ Richard Sulík, primárně vyhraněný pravicově liberální ekonom, Igor Matovič, primárně protestně zaměřený politik více extravagantního - happeningového politického stylu.

${ }^{28}$ Tím se rozumí prosazování agendy odlišné od tradičních stran.

${ }^{29}$ Časté a opakované pořádání mimoparlamentních happeningů, v parlamentu pak nevšední a okázalá vystupování jejích reprezentantů, hlavně Igora Matoviče, a to s pomocí demonstrativních předmětů či symbolů, jako jsou již zmiňované transparenty nebo trička s nápisy.

${ }^{30}$ Především obviňování z klientelismu a korupce.

${ }^{31}$ Levicový a sociálně demokratický SMER-SD vs. pravicové a liberálně konzervativní OLaNO.

${ }^{32}$ Jistým dokladem toho, že SMER-SD vadí představitelům OLaNO primárně kvůli konkrétní politice, a nikoliv ideově programovému zakotvení, mohou být např́klad ne úplně jasné postoje OLaNO k tzv. sociálním balíčkům, které v minulém období přijímala vláda Roberta Fica. OLaNO by tyto balíčky (po případné politické změně po volbách a nástupu pravice) nerušilo, a pokud v této souvislosti kritizovalo SMER-SD, tak opět v souladu s výraznou protikorupční rétorikou poukazovalo na to, že „politici kradnú“ (Topky.sk 2015b). Srov. např́íklad s postoji SaS, která chtěla dát sociální balíčky Ficovy vlády dokonce k Ústavnímu soudu SR (Topky.sk 2015b). Předseda SaS Richard Sulík dále např́íklad odmítal vstoupit do vládní koalice se stranou SMER-SD mj. i kvůli „nepřijatelné levicové politice“ (Sulik.sk 2016).
} 
znamení permanentních střetů obou politiků, které se v souladu s mnoha výše uvedenými záležitostmi značně vymykaly z běžného způsobu komunikace mezi politickými oponenty. Např́íklad po vyhlášení volebních výsledků v roce 2012 prohlásil Igor Matovič v reakci na přesvědčivé vítězství SMER-SD mj., že Slovensko čekají „štyri roky kradnutia a korupcie“ (SME 2012: 11). S blíźícími se volbami 2016 se svérázný zpo̊sob vystupování Igora Matoviče přímo úměrně stupňoval, zejména ve vztahu k lídrovi SMER-SD Robertu Ficovi. V předvolebních debatách ve Slovenské televizi např́klad oslovoval Roberta Fica "ten pán na druhej strane stola", „ten pán z Úradu vlády" (Rtvs.sk 2016).

Nevšední politický styl je určující pro politiku OLaNO i po volbách 2016, ve kterých se toto uskupení opět - stejně jako v uplynulém volebním období - ocitlo v opozici vůči vládě s nejsilnějším zastoupením strany SMER-SD, přičemž excentrické vystupování mělo postupem času spíše zesilující tendence. Za krátké období, které uběhlo od posledních parlamentních voleb, byla patrná řada ostrých výpadů představitelů OLaNO vůči reprezentantům SMER-SD, charakteristické je výrazné uplatňování politiky mimoparlamentními prostředky ${ }^{33}$ či pokračování již zmiňované politiky extravagance a happeningů. ${ }^{34}$

Tabulka 6: Hlavní mezníky ve vývoji subjektu OLaNO

\begin{tabular}{ll}
\hline Politický subjekt: & Obyčejní lidé-Nezávislé osobnosti (OLaNO) \\
Rok vzniku: & 2011 \\
První volby do NR SR: & 2012 \\
Zastoupení v NR SR: & $2012-2016,2016-$ \\
Účast ve vládě: & -
\end{tabular}

Zdroj: autoři dle Štatistický úrad Slovenskej republiky

\section{SIEǏ}

SIEŤ se etablovala na slovenské politické scéně ve volebním období 2012-2016. Vznikla jako reakce na poměry $\mathrm{v}$ jedné $\mathrm{z}$ tradičních politických stran - KDH a též jako reakce na dlouhodobou krizi slovenské pravice. Stranu SIEŤ založil Radoslav Procházka, politik s řadou dispozic, které mohl v politice zužitkovat. Je to významný odborník na ústavní právo, vysokoškolský pedagog a autor řady odborných publikací (např. Procházka 2011). Také absolvoval studia na prestižní vysoké škole Yale v USA (Vlčej 2015: 36).

Jako politik se již v rámci KDH vymaňoval svým nevšedním politickým stylem a v politických či mediálních kruzích byl vnímán jako nová tvář hnutí. Toto reflektovali do jisté míry i voliči v parlamentních volbách 2012, ve kterých se Radoslav Procházka se ziskem více než 40 tisíc preferenčních hlasů posunul z 10. na 4. místo

\footnotetext{
${ }^{33} \mathrm{~V}$ létě 2016 organizovaly OLaNO spolu s SaS sérii protestních shromáždění v souvislosti s tzv. kauzou Bonaparte (její podstatou je obviňování ministra vnitra a jednoho z klíčových politiků SMER-SD Roberta Kaliňáka z obchodních vazeb na kontroverzního podnikatele Ladislava Bašternáka).

${ }^{34}$ Lídr OL'aNO například přistavil mikrobus před programovou konferenci SMER-SD v ř́jnu roku 2016, jednalo se v tomto směru o jeden z dalších happeningů, pomocí kterého chtěl demonstrovat svou politiku, především na poli zápasu s klientelismem a korupcí.
} 
stranické kandidátky. V reakci na ne př́liš přesvědčivé volební výsledky ${ }^{35}$ se po volbách 2012 stále více prezentovali dva politici, kteří chtěli změnit KDH, stranu do té doby vnímanou jako př́liš zkostnatělou, nehybnou, bez výrazných oživujících impulsů. Byli to Daniel Lipšic a Radoslav Procházka. Oba po určitých pokusech prosadit své představy o politice v rámci $\mathrm{KDH}$ nakonec z $\mathrm{KDH}$ odešli a každý $\mathrm{z}$ nich založil svou novou formaci.

Po svém odchodu z KDH v únoru 2013 se Radoslav Procházka prosadil ve slovenské politice především kandidaturou v prezidentských volbách 2014. V nich akcentoval prohlubující se nespokojenost občanů se stávajícími politickými, zejména stranickými elitami. Již disponoval výhodami toho, že po svém vystoupení z KDH nebyl svázán s žádnou dosud etablovanou stranou, a tak komunikoval tomu odpovídající témata. Sliboval například ochranu veřejné správy před stranickými tlaky nebo podporu činnosti nezávislých kontrolních orgánů (Meštánková 2015: 45). V prezidentských volbách se Procházka prezentoval jako mladý kandidát. ${ }^{36}$ Tím chtěl vyjádřit kombinaci zkušenosti a nezkaženosti dvacetiletým působením v politice (Meštánková 2015: 45). Ve volbách využíval on-line forem komunikace, např́iklad šlo o vlastní webovou stránku, blogy či sociální sítě.

Radoslav Procházka projevoval jedné straně odstup od etablovaných politických stran a reflektoval nespokojenost voličů s dosavadní politikou, zároveň ale deklaroval zakotvení v pravé části politického spektra. V tomto směru je další podobou pokusu o zřetelnější, přesvědčivější, věrohodnější alternativu v tomto politickém prostoru charakteristickém dlouhodobou krizí. Voličský úspěch jedné z novějších podob slovenské pravice dokládá zejména srovnání dosažených volebních výsledků v prezidentských volbách 2014 dvou kandidátů - Radoslava Procházky a Pavla Hrušovského. ${ }^{37}$

Jistou mezifází v politické kariéře Radoslava Procházky ve volebním období 2012-2016 byl projekt Alfa, ve kterém se snažil soustředit zajímavé osobnosti usilující o změny ve slovenské politice. Lze říci, že to byl předstupeň k vytvoření politické strany. Strana SIEŤ totiž vznikla v polovině roku 2014 (viz Tabulku 7). Již krátce poté zaznamenala významné politické úspěchy v podobě relativně vysokých volebních preferencí, které se postupně ustálily v pásmu odpovídajícímu středně velké politické straně (zisk okolo 11-15\%). Na krátkou dobu mezi jejím vznikem a parlamentními volbami 2016 stabilizovala své postavení na slovenské politické scéně jako druhého voličsky nejoblíbenějšího politického subjektu za dlouhodobě nejúspěšnější SMER-SD.

Strana SIEŤ je, do jisté míry podobně jako SaS, projektem, který se etabloval na slovenské politické scéně v podmínkách dlouhodobé krize pravice. SIET chtěla rozšírit a doplnit nabídku ve standardní a etablované pravé části politického spektra. Zároveň chtěla být alternativou vůči dosavadním středopravicovým

\footnotetext{
${ }^{35}$ Před volbami 2012 deklarovalo KDH ambice dosáhnout dvojciferného volebního výsledku, ve volbách nakonec získalo pouze necelých $9 \%$.

${ }^{36} \mathrm{Na}$ billboardech používal heslo „Mladý prezident? Prečo nie!"

${ }^{37}$ Radoslav Procházka získal v prezidentských volbách $21,2 \%$ hlasů, a stal se tak třetím nejúspěšnějším kandidátem v pořadí za dvěma finalisty postupujícími do druhého kola Robertem Ficem a Andrejem Kiskou. Ve výrazném kontrastu je v tomto směru dosažený výsledek Pavla Hrušovského (pouhá $3 \%$ hlasů), který byl kandidátem jedné z dosud etablovaných pravicových stran - KDH.
} 
politickým stranám jako SDKÚ-DS nebo KDH. Jinými slovy v mnoha aspektech SIEŤ nepředstavovala zásadní anti-establishmentovou opozici vůči dosud fungujícímu schématu rozvrstvení slovenské politiky a jejích konfliktních linií. Zároveň však lze tuto stranu chápat jako nositelku četných prvků novosti.

V politice strany SIEŤ byla patrná kontinuita s dosavadními etablovanými (středo)pravicovými politickými stranami v rovině programové nebo personální. Strana v zásadě rozvíjela agendu typickou pro slovenskou pravici včetně tomu odpovídajícího vymezování se vưči vládní sociálně demokratické straně SMER-SD. V oblasti personální je příznačné, že se reprezentanty strany SIEŤ stali představitelé stávajících středopravicových formací. ${ }^{38}$ Týká se to zejména SDKÚ-DS. Do strany SIEŤ se v krátké době zapojili bývalí reprezentanti SDKÚ-DS Miroslav Beblavý a Martin Fedor. Souvislostí mezi SDKÚ-DS a stranou SIEŤ je ale více.

SIEŤ představovala na slovenské politické scéně do určité míry podobně koncipovaný subjekt jako před několika lety SDKÚ-DS. Mnozí političtí komentátoři obě strany srovnávali (Postoy.sk 2016). V obou případech jde o středopravicové formace formálně, nikoliv principiálně nebo fundamentálně jako u KDH nebo KDS, hlásící se ke křestanským ideovým hodnotám. ${ }^{39}$ Vedle toho však značně liberální především ve smyslu významné části jejich voličského zázemí. ${ }^{40}$ Jak SDKÚ-DS, tak i SIEŤ do značné míry charakterizují politický pragmatismus korespondující s potenciálem obsáhnout a zaujmout tzv. nevyhraněný střed. V neposlední řadě jsou analogie mezi SDKÚ-DS a uskupením SIEŤ dány také jejich volebními preferencemi. Relativně vysoké volební preference strany SIEŤ (kolem 15\%) byly podobné volebním preferencím svého času SDKÚ-DS a mnozí političtí pozorovatelé, jakož i sami představitelé hovořili o straně SIEŤ jako o lídrovi a hlavní síle slovenské pravice (Sme.sk 2014b).

Vznik strany byl jedním z projevů již zmiňované krize stávající slovenské pravice zejména, co se týče míry atraktivity jejích stávajících reprezentantů mezi voliči. SIEŤ vznikla v době zvýšeného rozkvětu nových politických stran. Příznačný je název strany, který nijak nevypovídá o jejím ideově programovém zaměření, zato je ale příkladem z řady marketingových či metaforických názvů. Sama SIEŤ zdůvodňuje název své strany mimo jiné tím, že je metaforou jejího chápání státu jako společenství, ve kterém by ti, kteří ho potřebují, měli najít pomoc a ochranu, zároveň však nepředepisuje lidem, jak mají žít (Siet.sk).

Další charakteristikou strany je nadměrné využívání moderních marketingových postupů při oslovování voličů. Prezentace pomocí billboardo̊, poutačů a hesel se projevilo již při zmíněné prezidentské kampani Radoslava Procházky (viz výše). Během roku 2015 byla zřejmá tzv. seznamovací kampaň mnohých politických stran, například SNS, která se chtěla představit se svým novým lídrem Andrejem Dankem. Takto se SIEŤ prezentovala tím, že po Slovensku vyvěsila množství billboardů a poutačů zejména s lídrem Radoslavem Procházkou.

\footnotetext{
${ }^{38}$ To v podmínkách dlouhodobě zvýšené míry stranicko-politických přeskupování na slovenské pravici však není př́liš překvapivé.

${ }^{39}$ Jak lídr SDKÚ-DS Mikuláš Dzurinda, tak lídr strany SIEŤ Radoslav Procházka vzešli z KDH.

${ }^{40}$ SDKÚ-DS i SIEŤ významnými aspekty své politiky oslovovaly liberální voliče zejména v městském prostředí.
} 
V květnu 2015 začala se soustavnou informační kampaní a v rámci ní na billboardech prezentovala tým svých sedmi lídrů. Marketingově zajímavá byla originální podoba jejich oblečení do národní hokejových dresů doprovozených heslem „Striedame!“. Byla to jasná narážka na dosud vládnoucí SMER-SD. SIEŤ se tak prezentovala jako středopravicová alternativa vưči sociální demokracii reprezentované SMER-SD. Ústředním heslem strany SIEŤ pro volby 2016 bylo „Dobrý štát slúži lud’om". Toto heslo vyjadřovalo zaměření strany na program dobrého fungování a zlepšení oproti současnému stavu státu. SIEŤ usilovala o omezení nadměrného vlivu státu na občana. Už bylo zmíněno chápání státu jako instituce, která nemá lidem zasahovat do jejich životů. SIEŤ dále například chtěla zeštíhlit strukturu vlády a omezit počet ministerstev (Sme.sk 2014a).

Dalším podstatným rysem politiky strany SIEŤ byl důraz na dobré fungování státu ve smyslu vymahatelnosti práva nebo potírání korupce. Toto se odvíjí již od profesního zaměření Radoslava Procházky. Dále se u formace SIEŤ projevuje, byt ne ve stejné míře nebo stejné podobě politického stylu to, co u jiných nových politických stran - profilují a vymezují se vůči stávajícímu (stranicko)politickému establishmentu zvýšeným důrazem na potírání takových jevů, jako je korupce a klientelismus.

SIEŤ se svými hesly, rétorikou nebo konkrétními nápady profilovala primárně jako strana prosazující dobrou správu státu. V tomto směru je možné též vnímat opakovaná označování lídra Radoslava Procházky jím samotným i politickými pozorovateli jako gazdy, v čemž se zrcadlí jistá symbolika dobrého hospodáře a pracovitosti. V prostředí krize politiky, důvěry občanů v politické reprezentace a fungování státu se strana s tímto založením celkem úspěšně trefila do vkusu a nálad nezanedbatelné části voličů, čemuž odpovídají její již zmiňované vysoké volební preference. S jejich vědomím se strana SIEŤ s blížícími se volbami netajila své ambice být po nich rozhodující vládní stranou, a to s Radoslavem Procházkou v roli premiéra. $^{41}$

V souladu s charakteristikou uskupení SIEŤ jako nové politické strany jsou některé další prvky typické pro tyto formace. Je to, stejně jako u SaS nebo OLaNO, na jedné straně slabé organizační rozvinutí, na druhé straně silná dominance lídra. U SIETě je viditelná snaha o jisté omlazení politiky, prostřednictvím strany se totiž do politiky zapojila řada lidí z mladší generace. Mladší lidé byli v popředí například v komunálních volbách v roce $2014^{42}$ a též kandidátka strany SIET̃ pro parlamentní volby 2016 sestávala ve značné míre z mladších nominantů.

\footnotetext{
${ }^{41} \mathrm{~V}$ ostrém rozporu s většinou předvolebních prognóz byla nakonec SIEŤ ve volbách 2016 výrazně neúspěšná (zisk pouze něco málo přes $5 \%$ hlasů) a stala se pouze menší doplňkovou stranou v širší vládní koalici se SMER-SD, SNS a MOST-HÍD. Analýzou tohoto aspektu se text nebude hlouběji zabývat.

${ }^{42} \mathrm{Na}$ primátorku Košic kandidovala za SIEŤ tehdy 37letá Alena Bašistová.
} 
Tabulka 7: Hlavní mezníky ve vývoji subjektu Siet'

\begin{tabular}{ll}
\hline Politický subjekt: & Siet \\
Rok vzniku: & 2014 \\
První volby do NR SR: & 2016 \\
Zastoupení v NR SR: & $2016-$ \\
Účast ve vládě: & - \\
\hline
\end{tabular}

Zdroj: autoři dle Štatistický úrad Slovenskej republiky

\section{SME RODINA}

Hnutí SME RODINA vzniklo v roce 2011 jako Strana občanů Slovenska. V roce 2015 ho převzal podnikatel Boris Kollár. Jeho nástup na politickou scénu a prosazení se zapadá do širšího kontextu odklonu voličů od etablovaných politických stran směrem ke stranám novým, ale můžeme též zmínit konání referenda o tradiční rodině v únoru 2015, v souvislosti s kterým bylo možné zaznamenat první vážnější politické projevy Borise Kollára. Ten se poměrně ostře vyjádřil k tématům referenda a v širším kontextu k dlouhodobě citlivé problematice registrovaných partnerství a postavení homosexuálů ve společnosti (Topky.sk 2015a).

Jak ukazuje Tabulka 8, politický postup hnutí SME RODINA vyvrcholil úspěchem v parlamentních volbách 2016 se ziskem téměř $7 \%$ hlasů. Některé jevy jsou podobné zejména OLaNO. Charakteristická je nevyvinutá organizační struktura v kombinaci s dominancí lídra. V případě OL'aNO je tato dominance dána jistou mírou propojení jeho politické a podnikatelské činnosti, anebo příbuzenskými vazbami a blízkými osobními vztahy s jeho nejbližšími spolupracovníky. Druhý jev je v případě SME RODINA patrný ještě v silnější podobě. Boris Kollár žil ve svém soukromém životě postupně s několika ženami, ${ }^{43} \mathrm{z}$ nichž mnohé se staly jeho spolupracovnicemi v rámci hnutí. Mj. i z tohoto hlediska je osoba Borise Kollára předmětem zájmu v souvislosti se světem šoubyznysu a bulváru.

Také u SME RODINA máme co do činění s jevem typickým pro nové politické strany, a to silný anti-establishment apel, který je zacílen především do společensky citlivé oblasti boje proti korupci a klientelismu. Rovněž hnutí SME RODINA zdůvodňovalo svůj nástup na politickou scénu neutěšeným stavem politické scény, jejichž reprezentanti pouze hájí zájmy finančních skupin a oligarchů vysávajících státní rozpočet (Hnutie-smerodina.sk nedat.).

U některých politických stran je patrná absence jejich zřetelné ideově programové orientace. $\mathrm{V}$ případě SME RODINA je naopak ideologické vyhranění v některých směrech velmi jasné. Tuto formaci lze rámcově považovat za konzervativní, přičemž v některých konkrétních oblastech zaujímá přísně konzervativní stanoviska. V prvním př́ípadě to je důraz na tradiční rodinu a podpora prorodinné politiky (Hnutie-smerodina.sk 2016). Ve druhém případě je to migrační krize, v souvislosti se kterou SME RODINA mluví o vnějším ohrožení Slovenska a jeho kultury muslimskou invazí do Evropy (Hnutie-smerodina.sk nedat.).

\footnotetext{
${ }^{43}$ Konkrétně s osmi ženami má sedm dětí.
} 
Výše uvedeným charakteristikám SME RODINA jako značně nestandardního politického subjektu nebo jeho programové profilaci odpovídá částečně jeho personální skladba. Souvislost této formace se světem bulváru a šoubyznysu se dá ukázat v oblasti personální tím, že jí reprezentují někteří lidé typičtí právě pro toto prostředí. Takto je součástí hnutí SME RODINA například Martina Šimkovičová, bývalá moderátorka komerční TV Markíza, nebo Petra Krištúfková, jedna z bývalých partnerek Borise Kollára. Na druhé straně z lidí, kteří se dosud do politiky aktivně zapojili, jsou součástí politické reprezentace SME RODINA Milan Krajniak a Peter Pčolinský. Oba se dosud pohybovali v prostředí KDH (spolupracovníci některých jeho klíčových reprezentantů, hlavně Daniela Lipšice). V tomto směru jde o další př́íklady politiků, kteří vzešli z KDH a následně se podíleli na formování další konzervativně orientované formace na slovenské politické scéně.

Tabulka 8: Hlavní mezníky ve vývoji subjektu Sme rodina

\begin{tabular}{ll}
\hline Politický subjekt: & Siet \\
Rok vzniku: & 2011 (jako Strana občanů Slovenska, pod současným názvem \\
& od roku 2015) \\
První volby do NR SR: & 2016 \\
Zastoupení v NR SR: & $2016-$ \\
Účast ve vládě: & -
\end{tabular}

Zdroj: autoři dle Štatistický úrad Slovenskej republiky

\section{ChARAKTERISTIKY POLITICKÝCH STRAN DLE TYPOLOGIE NOVOST}

Jak ukazuje Tabulka č. 9, v každých volbách od roku 2010 do roku 2016 byl úspěšný některý z nových politických subjekti̊, což vždy proměnilo charakter stranické soutěže. Bez zajímavosti není ani to, že u stran, které se v rámci stranického systému postupně etablovaly, docházelo jak ke snižování, tak ale i k navyšování voličské podpory. Z hlediska analýzy pak byly nejatraktivnější volby 2016, ve kterých úspěch zaznamenaly hned dva nové subjekty.

Tabulka 8: Hlavní mezníky ve vývoji subjektu Sme rodina

\begin{tabular}{lccc}
\hline Politická strana & Volby 2010 & Volby 2012 & Volby 2016 \\
\hline SaS & $12,1 \%$ & $5,9 \%$ & $12,1 \%$ \\
OLaNO & - & $8,6 \%$ & $11 \%$ \\
SME RODINA & - & - & $6,6 \%$ \\
SIEŤ & - & - & $5,6 \%$ \\
\hline
\end{tabular}

Zdroj: autoři dle Štatistický úrad Slovenskej republiky

Na základě výše uvedených představení teoretických konceptů a následném rozboru charakteristiky sledovaných politických subjektů je možné provést shrnutí jejich podstatných rysů a zasadit tyto strany do uvedených typologií. U některých poli- 
tických stran jsou některé aspekty více zřejmé, u jiných lze zařazení více problematizovat (viz Tabulku 10).

$\mathrm{V}$ případě SaS se jedná o stranu poměrně silně ideologicky profilovanou. Charakteristická je pro ni důsledná obhajoba myšlenek pravicového ekonomického neoliberalismu a s tím související silné ideové vymezování se proti levici. Stranu tak lze zařadit mezi očištovatele, a to i proto, že dosavadní pravicové strany nebyly dostatečně věrohodné a důsledné v předkládání neoliberální ekonomické politiky. Ideologické vyhranění SaS podtrhuje euroskepticismus, charakteristický minimálně pro část strany, zejména je to předseda Richard Sulík. Vedle toho je strana typická prosazováním konkrétních zájmů, především agenda boje proti klientelismu a korupci. Z hlediska typologie Allana Sikka tak může být SaS zařazena zároveň do kategorií očištovatelé či mluvčí, přičemž obojí se prolíná především v tom smyslu, že nadměrná protikorupční rétorika SaS je téměř výhradně selektivně zaměřená vůči levicovému SMER-SD.

Formaci OLaNO můžeme zejména s ohledem na její nevšední politický styl celkem snadno charakterizovat mnoha přídomky, které používají političtí analytici, pozorovatelé nebo komentátoři. Více než v případě SaS jsou přítomny výrazné prvky novosti. Straně OLaNO dominuje osoba lídra Igora Matoviče nejen politicky, ale především coby podnikatele (jednatele firmy), který stranu financuje a provozuje z velké části ze zdrojů svého podnikání. Charakterizovat lze OLaNO i jako mediální stranu - zde máme co do činění s rolí lídra Igora Matoviče coby jednatele sítě bezplatných regionálních tiskovin, která je nezastupitelným nástrojem účinného politického marketingu. A konečně lze bez problémů vnímat OLaNO jako stranu protestu, anti-politickou stranu, vymezující se vůči stávající politice a politickému establishmentu.

Významná je v tomto směru silná a agresivní protikorupční rétorika (v kontextu korupce jako jednoho z nejvážnějších problémů určujících nálady mezi voliči) a nevšední (extravagantní, happeningový) politický styl zejména lídra. OLaNO je dále ukázkovým př́kladem politického subjektu bez jasné a rozvinuté organizační struktury, kromě několika nejbližších spolupracovníků Igora Matoviče disponuje namísto členů spíše amorfní sítí sympatizantů. OLaNO z hlediska ideologického charakterizuje ne př́liš jasné vyhranění, na druhou stranu je rámcově zařazené do určité části politického spektra (OLaNO se hlásí k liberálně konzervativní pravici).

$\mathrm{S}$ ohledem na toto slabší ideologické vyhranění a zároveň silný akcent na konkrétní společensky citlivá témata můžeme OLaNO zařadit do kategorie mluvčích. Dále je v tomto směru vhodný čtvrtý Sikkův typ projekt novosti (project of newness). OLaNO splňuje charakteristiku strany vyznačující se prvky zařazení do části politického spektra již obsazeného jinými politickými subjekty, program slibů v oblasti očištění politického života zejména od korupce a místo v prostoru politického mainstreamu, nikoliv antisystémová pozice (viz poznámka č. 13). Kombinace silných prvků anti-politiky, jisté míry (ne ale zřetelného) ideologického zařazení a dominance a extravagantního stylu lídra se v souhrnu projevuje jedním nepřehlédnutelným znakem politiky OLANO, kterým je nadměrná míra konfrontace jeho předsedy Igora Matoviče s lídrem SMER-SD Robertem Ficem. ${ }^{44}$

\footnotetext{
${ }^{44} \mathrm{Zde}$ by se dal připomenout i Lucardieho (2000) typ idiosynkratické (idiosyncratic nebo personal vehicle) strany konstruované za účelem realizace osobních ambicí lídra.
} 
V případě strany SIEŤ je patrná politika artikulace konkrétních zájmů a problémů. Lze připomenout hesla o dobře fungujícím státě a jeho spravování (symbol gazdy - dobrého hospodáře) nebo akcenty na konkrétní témata a problémy (zeštíhlení státního aparátu, problém korupce a klientelismu). SIET charakterizuje zakotvení v určité části politického spektra (středopravicová formace liberálně konzervativního zaměření), její ideologické vyhranění je však spíše slabé, strana je pragmatická, což se projevilo například tím, že v době vrcholící konfrontační předvolební kampaně tato strana (na rozdíl od SaS nebo OLaNO) výslovně nevyloučila spolupráci se SMER-SD a po volbách (samozřejmě v podmínkách změněné politické situace) s ní vstoupila do vládní koalice.

Pro stranu SIEŤ jsou silně charakteristické prvky novosti především ve smyslu způsobu a okolnostem vzniku, názvu, některých aspektů fungování nebo způsobů komunikace s voliči. Z hlediska typologie Allana Sikka lze SIEŤ zařadit primárně do kategorie mluvčích (především artikulace konkrétních zájmů, slabší ideologické vyhranění). Z dnešního pohledu (s přihlédnutím k vývoji po volbách 2016) je možné brát SIEŤ jako příklad strany jednoho použití - charakteristické je krátkodobé prosazení se strany v kombinaci se strategií orientovanou na získání vládních postů (což se po volbách 2016 stalo, byṫ za jiných okolností, než si patrně i sami představitelé strany SIEŤ představovali).

Strana SME RODINA disponuje málo rozvinutou organizační strukturou a silnou rétorikou proti etablované politice. Podobně jako u OLaNO je typický akcent na konkrétní témata, přičemž v případě SME RODINA je více výrazná (i s ohledem na okolnosti vzniku strany, viz výše) konzervativní, antiglobalistická, antiimigrační a tradicionalistická agenda, která vyniká v současných střetech o četná domácí i mezinárodní politická témata. Také v případě SME RODINA je specifický její lídr - Boris Kollár je bohatým podnikatelem, který tuto stranu založil a je tím, kdo určuje její politiku. Stranu je možné zařadit do kategorie mluvčích (politika konkrétních témat) a též jí vnímat jako projekt novosti (v zásadě podobné záležitosti uvedené výše v souvislosti s hodnocením OLaNO).

Pro všechny čtyři sledované politické strany je příznačný jev v podobě výrazné dominance lídra. Ta je dána několika skutečnostmi - osobním charismatem a s tím souvisejícím politickým stylem a komunikačními dovednostmi, v některých případech jistého odborného renomé (Radoslav Procházka), v jiných případech propojení politické a podnikatelské sféry (Igor Matovič) nebo dokonce silných osobních, případně rodinných vazeb (zejména Boris Kollár, ale do jisté míry také Igor Matovič). Ve všech případech dále platí nepřímá úměrnost ve smyslu čím slabší a méně vyvinutá organizační struktura (a málo početná členská základna), tím silnější dominance lídra. Faktická dominance lídra jde ruku v ruce s jejich silnými ambicemi. Předseda SaS Richard Sulík deklaroval po nečekaném úspěchu své strany po volbách 2016 své premiérské ambice (předseda vlády potenciální středopravicové koalice bez vítězné SMER-SD). Předseda SIETě Radoslav Procházka byl považován za vážného kandidáta na premiéra (např. Pravda.sk 2015) a též sám netajil své ambice v tomto směru v době před volbami, kdy SIEŤ měla ještě vysoké volební preference. Dominance lídrů byla navíc v případě již delší dobu existujících stran (tj. SaS a OLaNO) postupem času ještě spíše upevňována (odchody nespokojenců 
z SaS a vznik konkurenčního SKOKu, značná míra obměny poslaneckého klubu OLaNO).

Tabulka 10: Souhrn klasifikace zkoumaných politických stran

\begin{tabular}{ll}
\hline Politická strana & Charakteristika dle novosti \\
\hline SaS & očištovatel, mluvčí \\
OLaNO & mluvčí, projekt novosti \\
SIET̃ & mluvčí \\
SME RODINA & mluvčí, projekt novosti \\
\hline
\end{tabular}

Zdroj: autoři

\section{ZÁvĚR}

Příspěvek se zaměřil na čtyři nové politických subjektů na slovenské politické scéně v posledních třech volebních obdobích. Přes mnohé komplikace byly zdůrazněny zásadní skutečnosti, které jsou přes četné odlišnosti u dotyčných subjektů spojující. Zejména jde o jejich roli ve smyslu alternativ k dlouhodobě etablovaným formacím, organizační strukturu a význam lídra. Dané subjekty tak představují vhodně a logicky vymezený předmět výzkumu. Sledované politické strany byly následně explicitně zařazeny do vymezených kategorií dle Sikkova konceptu novosti. Z textu a shrnující klasifikační tabulky (viz Tabulku 10) je patrné, že v některých případech je charakteristika sledovaných subjektů celkem zřetelná. V tomto směru je třeba reflektovat skutečnost, že novost často není žrejmá ani konceptuálně, ani empiricky (viz Hanley 2011: 131; srov. Šárovec 2018: 83). To samotný výzkum nových stran poněkud znesnadňuje, ale neznamená to, že by na něj měl výzkumník a priori rezignovat. Politické strany jako dynamičtí aktéři mohou svo̊j charakter působení měnit, což následně determinuje i jejich samotnou profilaci, včetně zařazení do daných kategorií. ${ }^{45}$ Opodstatnění závěrů zvláště vynikne, pokud si postavení a význam sledovaných politických stran uvědomíme v kontextu kooperačně-konkurenčních interakcí ve stranickém systému, a to v období před a zejména po parlamentních volbách 2016.

Uzavření vládní koalice po volbách 2016 potvrdilo význam dimenze mezistranické soutěže v podobě protikladu mezi zavedenými a novými politickými stranami. Vládní koalice uzavřená po volbách 2016 byla velmi heterogenní z hlediska ideově programového, ale relativně homogenní v tom smyslu, že byla sestavena z převážně zavedených politických subjektů. Neplatí to však absolutně a v tomto směru se zároveň projevily i jiné aspekty.

Účast (nové) strany SIEŤ ve vládní koalici převážně zavedených politických subjektů byla umožněna díky její slabší ideologické profilaci (ne tak výrazný protiklad vůči nejsilnější koaliční formaci SMER-SD, zároveň programová blízkost

\footnotetext{
${ }^{45} \mathrm{Na}$ tomto místě je vhodné připomenout poznámku Seána Hanleyho (2011: 127), který ve své analýze zaměřené na Českou republiku připouští směšování všech čtyř prvků jednotlivých apelů novosti, a dokonce i jejich vzájemný překryv. Mimoto podotýká, že v některých případech strany přecházejí od jedné skupiny ke druhé. Tato realita se potvrdila v případě výzkumu českého stranického systému (viz Hanley 2011; Šárovec 2018) a potvrdila se i v př́padě analýzy apelů novosti v rámci slovenského stranického systému.
} 
k další koaliční straně MOST-HíD ${ }^{46}$ ), a též jistým prvkům etablovanosti (účast politiků zavedených stran KDH a SDKÚ-DS na formování SIEŤe). S tím souviselo relativně umírněné vystupování vůči zavedené politice. Naproti tomu v případě SaS byla vyloučena účast na vládní koalici s nejsilnějším sociálně demokratickým SMER-SD s ohledem na její silné ideologické vyhranění, ale zároveň též kvưli silnému antiestablishmentovému (antikorupčnímu) apelu, zaměřenému ale téměř výhradně selektivně vůči SMER-SD.

U OLaNO a SME RODINA dominoval především výrazný antiestablishmentový apel a protestní rétorika vůči etablované politice. To lze také brát jako primární důvody a logické zdůvodnění toho, proč byla vyloučena spoluúčast těchto dvou subjektů na vládní koalici s převážně zavedenými stranami jako SMER-SD nebo SNS. Vedlejší roli v tomto směru hrála ideologická motivace (ne tak silná, ale přesto protiklad liberálně konzervativního OLaNO a konzervativní SME RODINA na straně jedné a sociálně demokratického SMER-SD na straně druhé). Konfliktní linie mezi zavedenými a novými politickými stranami tedy zafungovala, ne však paušálně, ale v souladu se specifiky a dílčími rozdíly mezi zkoumanými subjekty.

Závěry založené především na politické realitě vzniklé v důsledku parlamentních voleb v roce 2016 nemohou samozřejmě automaticky vést ke všeobecnějším konstatováním, přesto je třeba vnímat, že sledované jevy se utvářely právě v průběhu tř́ posledních volebních období a jejich jistou akumulaci bylo možno zaznamenat právě v roce 2016. Zároveň politická konstelace vzniklá po volbách v roce 2016 (zformování vládní koalice a opozice) umožnila interpretovat a problematizovat zkoumané jevy vztahující se $\mathrm{k}$ tematice zavedených a nových politických stran, a to nejen v konkrétním čase, ale i z hlediska procesu formování a vývoje politické scény. Zda to však zakládá dlouhodobé trendy v podobě utváření určitého nového modelu slovenského stranického systému, je možné zhodnotit až s delším časovým odstupem.

Tato studie by tak s ohledem na všechny aspekty jejího tematického zaměření měla být chápána především jako jeden $\mathrm{z}$ vkladů do problematiky systematického zkoumání nových politických stran. I z toho důvodu lze legitimně považovat za užitečné tento směr výzkumu dále kontinuálně prohlubovat.

\section{SEZNAM POUŽItÝCH ZKRATEK}

KDH - Křestanskodemokratické hnutí

KDS - Konzervativní demokraté Slovenska

LS-HZDS - Lidová strana-Hnutí za demokratické Slovensko

LSNS - Lidová strana Naše Slovensko

MOST-HÍD - MOST-HÍD polgári párt občanská strana

NOVA

OKS - Občanská konzervativní strana

OLaNO - Obyčejní lidé a nezávislé osobnosti

$\mathrm{SaS}$ - Svoboda a Solidarita

\footnotetext{
${ }^{46} \mathrm{Na}$ tomto místě můžeme též zohlednit skutečnost, že po volebním neúspěchu SIEŤe (viz poznámku výše) a jejím následném faktickém rozpuštění přešla značná část jejích představitelů právě do strany MOST-HÍD (Andrej Hrnčiar, Martin Fedor).
} 
SDKÚ-DS - Slovenská demokratická a křestanská unie-Demokratická strana SIET

SKOK - Slovenská občanská koalice - Evropští liberální demokraté

SME RODINA - SME RODINA - Boris Kollár

SMER-SD - SMER-sociální demokracie

SMK - Strana madarské koalice

SNS - Slovenská národní strana

\section{Biblografie}

Arter, D. 2016. „When New Party X Has the 'X Factor': On Resilient Entrepreneurial Parties." Party Politics 22 (1): 15-26, https://doi.org/10.1177/1354068813509523.

Barnea, S., G. Rahat. 2010. „Out with the Old, In with the 'New': What Constitutes a New Party?" Party Politics 17 (3): 303-320, https://doi.org/10.1177/1354068810369148.

Blaha, L., R. Žanony. 2008. „SMER-SD: od pragmatizmu k sociálnej demokracii.“ Př́spěvek přednesený na konferenci Sociálna demokracia po volbách 2006 na Slovensku. Bratislava, 23.-24. 5. 2008.

Bolleyer, N., E. Bytzek. 2016. „New Party Performance after Breakthrough: Party Origin, Building and Ledership. " Party Politics OnlineFirst: 1-11, https://doi.org/10.1177/ 1354068815626604 .

Conti, N., V. Memoli. 2015. „The Emergence of a New Party in the Italian Party System: Rise and Fortunes of the Five Star Movement." West European Politics 38 (3): 516-534, https://doi.org/10.1080/01402382.2014.996377.

Deutschlandfunk.de. 2016. „EU und Slowakei. 'Behalten Sie das Geld!'“ [online] Deutschlandfunk [cit. 8. 11. 2018]. Dostupné z: http://www.deutschlandfunk.de/eu-und-slowakeibehalten-

sie-das-geld.694.de.html?dram:article $\backslash$ id $=365986$.

Deegan-Krause, K., T. Haugton. 2015. „Hurricane Season. Systems of Instability in Central and East European Party Politics. "East European Politics 85 Societies 29 (1): 61-80, https://doi.org/10.1177/0888325414566072.

Engler, S. 2016. „Corruption and Electoral Support for New Political Parties in Central and Eastern Europe." West European Politics 39 (2): 278-304, https://doi.org/10.1080/ 01402382.2015 .1084127$.

Europskenoviny.sk. 2015. „Sulík zaútočil na Merkelovú: S utečencami robíte ničivú a nezodpovednú politiku!" [online] Európske noviny. Brusel - Štrasburg - Bratislava, 6. 10. 2015 [cit. 8. 11. 2018]. Dostupné z: https://europskenoviny.sk/2015/10/06/sulik-zautocilna-merkelovu-s-utecencami-robite-nicivu-a-nezodpovednu-politiku/.

Gyarfášová, O., M. Bahna, M. Slosiarik. 2017. „Sila nestálosti: volatilita voličov na Slovensku vo volbách 2016. "Středoevropské politické studie/Central European Political Studies Review 14 (1): 1-24, https://doi.org/10.5817/cepsr.2017.1.1.

Hanley, S. 2011. „Dynamika utváření nových stran v České republice v letech 1996-2010: hledání možných příčin politického zemětřesení. " Sociologický časopis/Czech Sociological Review 47 (1): 115-136.

Havlík, V., P. Voda. 2016. „The Rise of New Political Parties and Re-Alignment of Party Politics in the Czech Republic." Acta Politologica 8 (2): 119-144.

Henderson, K. 2001. „Euroscepticism or Europhobia: Opposition attitudes to the EU in the Slovak Republic." SEI Working Paper No. 50. Brighton: Sussex European Institut. 
Hino, A. 2012. New Challenger Parties in Western Europe. London: Routledge.

Hlavnespravy.sk. 2015. „Matovič tvrdí, že premiér Fico má na Belize milióny dolárov, Fico podáva na Matoviča trestné oznámenie." [online] Hlavné správy. Konzervatívny denník [cit. 8. 11. 2018]. Dostupné z: http://www.hlavnespravy.sk/matovic-tvrdi-ze-premier-ficaze-ma-na-bize-miliony-dolarov-fico-podava-na-matovica-trestne-oznamenie/657365.

Hloušek, V., L. Kopeček. 2004. Konfliktní demokracie. Moderni masová politika ve střední Evropě. Brno: Mezinárodní politologický ústav.

Hnutie-smerodina.sk nedat. „Naše hnutie." [online] Sme rodina. Boris Kollár [cit. 8. 11. 2018]. Dostupné z: http://hnutie-smerodina.sk/o-nas/.

Hnutie-smerodina.sk. 2016. „Programové priority hnutia SME RODINA - BORIS KOLLÁR 2016." [online] Sme rodina. Boris Kollár [cit. 2018-11-08]. Dostupné z: https: //hnutie-smerodina.sk/Program-Hnutia-Sme-Rodina.pdf.

Hynčica, P. 2007. „Volby 2006 a změna vlády na Slovensku. “ Politologická revue 13 (1): $129-150$.

Hynčica, P., P. Maškarinec, L. Novotný. 2017. Euroskepticismus ve střední Evropě. Praha: Academia.

Charvát, J., P. Just. 2016. Krize politického stranictví a noví straničtí aktéri $v$ české politice. Praha: Metropolitan University Prague Press.

Charvát, J., P. Just. 2018. „Politické zemětřesení? Dynamika stranického systému na Slovensku od roku 2002." Politické vedy 21 (1): 24-57, http://dx.doi.org/10.24040/ politickevedy.2018.21.1.24-57.

Kopeček, L. 2007. Politické strany na Slovensku 1989-2006. Brno: Centrum pro studium demokracie a kultury.

Krno, S. 1999. Politické strany krajín východnej Európy. Nitra: Univerzita Konstantina Filozofa.

Leška, D. 2010. „Vývoj politickej scény na Slovensku a európske politické strany. “ Pp 179215 in M. Goňcová a kol. Evropská politická společnost. Brno: Masarykova univerzita.

Lucardie, P. 2000. „Prophets, Purifiers and Prolocutors. Towards a Theory on the Emergence of New Parties." Party Politics 6 (2): 175-185, https://doi.org/10.1177/ 1354068800006002003.

Maškarinec, P., P. Bláha. 2014. „For whom Bell Tolls: Grievance Theory and the Rise of New Political Parties in the 2010 and 2013 Czech Parliamentary Elections. "Sociológia 46 (6): 706-731.

Mesežnikov, G. 2013. „Rise and Fall of New Political Parties in Slovakia.“ Pp 53-82 in Z. Bútorová, O. Gyarfášová, G. Mesežnikov. Alternative Politics? The Rise of New Political Parties in Central Europe. Bratislava: Institut pre verejné otázky.

Meštánková, M. 2015. „Vývoj zmien vo využívaní marketingovej komunikácie v prezidentských volbách 2014 na Slovensku. " Pp 39-49 in P. Juhás, M. Hrušovský. Premeny postavenia prezidentov v politických systémech. Trnava: FSV UCM v Trnave.

Michelko, R. 2012. „KDH - stagnácia ako princíp.“ [online] Slovenské národné noviny, 10. 7. 2012 [cit. 8. 11. 2018]. Dostupné z: http://snn.sk/kdh-stagnacia-ako-princip/.

Michelko, R. 2016. „Proces tvorby novej slovenskej vlády určite nebude ani lahký, ani rýchly. Volič: Politka sa musí zmenit! “ Slovenské národné noviny 34 (11): 6.

Noviny.sk. 2017. „Trapnučký koniec nahnedlého liberála." [online], Noviny.sk, 26. 1. 2017 [cit. 8. 11. 2018]. Dostupné z: https://www.noviny.sk/komentare/174159-trapnuckykoniec-nahnedleho-liberala.

Perottino, M. 2015. „Expertíza v českých politických stranách: poznámky k teoretickému a praktickému rámci." Acta Politologica 7 (2): 119-132. 
Postoy.sk. 2016. „Prečo bude Procházka opät skokanom voleb." [online] Postoy.sk, 14. 1. 2016 [cit. 8. 11. 2018]. Dostupné z: https://www.postoj.sk/9870/preco-bude-prochazkaopaet-skokanom-volieb.

Pravda.sk. 2015. „Prieskum: Najväčšie šance nahradit Fica má Procházka." [online] Pravda.sk, 26. 12. 2015 [cit. 8. 11. 2018]. Dostupné z: https://spravy.pravda.sk/ parlamentne-volby-2016/clanok/378131-prieskum-najvacsie-sance-nahradit-fica-a-smersd-ma-prochazka-a-siet/.

Pravda.sk. 2016. „Weisenbacher: Strana OLaNO funguje ako rodinná firma.“ [online] Pravda.sk, 26. 10. 2016 [cit. 8. 11. 2018]. Dostupné z: http://spravy.pravda.sk/domace/ clanok/409126-weisenbacher-strana-olano-funguje-ako-rodinna-firma/.

Procházka, R. 2011. L’ud a sudcovia v konštitučnej demokracii. Plzeň: Aleš Čeněk.

Rtvs.sk. 2016. „Parlamentné volby 2016 - diskusi.“ [online] RTVS [cit. 8. 11. 2018]. Dostupné z: https://www.rtvs.sk/televizia/archiv/10305.

Sas.sk. 2016. „SaS. Volebný program.“ [online] Sloboda a solidarita [cit. 8. 11. 2018]. Dostupné z: http://www.sas.sk/program/file/4330/SaS\_volebny\_program.pdf.

Siet.sk. „O strane. Čo je Siet? Siet ako symbol." [online] Siet [cit. 8. 11. 2018]. Dostupné z: http://siet.sk/o-strane/.

Sikk, A. 2005. „How Unstable? Volatility and the Genuinely New Parties in Eastern Europe." European Journal of Political Research 44 (3): 391-412, https://doi.org/10.1111/ j.1475-6765.2005.00232.x.

Sikk, A. 2012. „Newness as a Winning Formula for New Political Parties. " Party Politics 18 (4): 465-486, https://doi.org/10.1177/1354068810389631.

SME. 2012. „Matovič prekrúžkoval pravicu. “ SME, 12. 3. 2012: 11.

Sme.sk. 2014a. „Procházka chce zrušit tri ministerstvá, ukázal program." [online] SME [cit. 8. 11. 2018]. Dostupné z: https://domov.sme.sk/c/7209016/prochazka-chce-zrusittri-ministerstva-ukazal-program.html.

Sme.sk. 2014b. „Procházka: Nechcem byt lídrom pravice. Gazda je krajšie slovo. [online] SME [cit. 8. 11. 2018]. Dostupné z: https://domov.sme.sk/c/7140772/prochazkanechcem-byt-lidrom-pravice-gazda-je-krajsie-slovo.html\#ixzz4cpDo0JU9.

Stauber, J. 2017. „Institutionalization of Nationalized Party System: The Czech Case.“ Acta Politologica 9 (3): 46-65.

Sulik.sk. 2016. „Aj pravicový volič si zaslúži istoty." [online] Richard Sulík. Spravme Slovensko lepšim!, 20. 1. 2016 [cit. 8. 11. 2018]. Dostupné z: http://sulik.sk/aj-pravicovyvolic-si-zasluzi-istoty/.

Š́rovec, D. 2016. „Nové politické strany: novost, teoretické koncepty a možnosti jejich využití v ČR." Politics in Central Europe 12 (2S): 9-27.

Šárovec, D. 2017. „Krajské volby 2016 a nové politické strany v České republice. " Central European Journal of Politics 3 (2): 1-25.

Šárovec, D. 2018. „Nástup nových politických stran v ČR od roku 2013: hnutí ANO 2011 a Úsvit př́mé demokracie pohledem konceptu novosti. " Sociológia 50 (1): 78-113.

Štatistický úrad Slovenskej republiky. 2010. „Volby do NR SR 2010.“ [online] Śtatistický úrad Slovenskej republiky [cit. 8. 11. 2018]. Dostupné z: http://volby.statistics.sk/nrsr/ nrsr2010/.

Štatistický úrad Slovenskej republiky. 2012. „Volby do NR SR 2012.“ [online] Štatistický úrad Slovenskej republiky [cit. 8. 11. 2018]. Dostupné z: http://volby.statistics.sk/nrsr/ nrsr2012/. 
Štatistický úrad Slovenskej republiky. 2016. „Volby do NR SR 2016.“ [online] Štatistický úrad Slovenskej republiky [cit. 8. 11. 2018]. Dostupné z: http://volby.statistics.sk/nrsr/ nrsr2016/.

Topky.sk. 2015a. „Podnikatel Kollár šokoval Slovensko: Pozrite sa, ako sa vyjadril na adresu homosexuálov! “ [online] Topky.sk, 24. 1. 2015 [cit. 8. 11. 2018]. Dostupné z: http:// www.topky.sk/cl/100313/1452349/Podnikatel-Kollar-sokoval-Slovensko--Pozrite-sa--ako -sa-vyjadril-na-adresu-homosexualov- .

Topky.sk. 2015b. „Opozícia reaguje na smerácke sociálne balíčky: Máme sa bát spojenia Matoviča s Ficom?" [online] Topky.sk [cit. 8. 11. 2018]. Dostupné z: http://www.topky.sk/ cl/100535/1492443/Opozicia-reaguje-na-smeracke-socialne-balicky--Mame-sa-batspojenia-Matovica-s-Ficom-.

Vlčej, J. 2015. „Prezidentské volby v SR z hladiska historickej perspektívy so zameraním na volby 2014." Pp 28-38 in P. Juhás, M. Hrušovský. Premeny postavenia prezidentov $v$ politických systémech. Trnava: FSV UCM v Trnave.

Žúborová, V. 2015. „Newcomers in Politics. The Success of New Political Parties in the Slovak and Czech Republic after 2010. " Baltic Journal of Law 83 Politics 8 (2): 91-111, https://doi.org/10.1515/bjlp-2015-0020.

\section{SUMMARY}

In our paper, we have analyzed four new political parties that were established on the Slovak political scene over the course of the last three election periods (2010-2012, 20122016 and 2016-2020) - Freedom and Solidarity (SaS), Ordinary People (OLaNO), the Slovak Conservative Party (SIE T) and We Are Family. We have focused on analyzing the typology of newness according to the concepts of Allan Sikk and characterized the entities in question based on these concepts. At the same time, the paper is aimed at analyzing the dimension of inter-party competition and the operation of the Slovak party system in the sense of established political parties versus new parties. By analyzing the program characteristics, organization structure, personnel of the parties, or the operation and role of these political parties, we have reached conclusions that incorporate the parties into individual categories according to A. Sikk's concept. We have evaluated SaS as purifiers (strong ideology in the sense of promoting right-wing neoliberal policy) and prolocutors (specific topics, primarily the agenda of the battle against clientelism and corruption). We have placed OlaNO into the category of prolocutors (also specific topics primarily in the field of the fight against clientelism and corruption). In terms of A. Sikk's typology, the SIEŤ party can also be placed primarily in the category of prolocutors (primarily the articulation of specific interests, weaker ideological distinction, greater emphasis on the idea of a functioning state and administering it in terms of specific topics and problems, for example reducing the size of the state apparatus or also the issue of corruption and clientelism). Similarly to OlaNO, We Are Family party is typical for its accent on specific issues with a conservative agenda that comes to the forefront (sometimes almost rigidly). In this case as well, we can view the given group as a category of speaker. We also see the OlaNO and We Are Family parties as a project of newness that is typical for its elements of involvement in a segment of the political spectrum already taken by other political entities (in this case the right side of the political spectrum) and a program of promises in the area of purifying political life, primarily corruption. For all four researched political parties, the distinct dominance of its leader is typical, a factor which highlights the significance and elements of newness. We have strongly emphasized many shared characteristics of the four studied parties, which corresponds with the fact that lines of conflict can be observed in the contemporary Slovak party system as well as the corresponding differences between the established parties and new parties. Proof of this can be seen in the makeup of the government coalition agreed upon in the 2016 elections, which was highly heterogeneous in terms of its program but relatively homogeneous in 
terms of being made up primarily of established political entities. This, however, does not apply absolutely. On the contrary, it is necessary to consider the numerous specific elements of the studied political parties and the differences between them that we have reflected, analysed and assessed in the form of conclusions representing the fundamental outputs of our paper. 